\title{
難聴，め屯いで発症した脳幹部海綿状血管腫の一症例
}

\author{
佐久間 仁 ${ }^{1)} \cdot$ 大河内幸男 $11 \cdot$ 馬場 陽子1) $\cdot$ 大谷 巌 ${ }^{1)}$ \\ 平山 和美 ${ }^{2)} \cdot$ 佐藤 正憲 3$) \cdot$ 児玉南海男 ${ }^{3)}$
}

\section{A Case Report of Brainstem Cavernous Angioma Associated with Hearing Loss and Dizziness}

\author{
Hitoshi Sakuma, Yukio Ohkouchi, Yohko Baba, Iwao Ohtani, \\ Kazumi Hirayama, Masanori Sato and Namio Kodama \\ (Fukushima Medical College)
}

\begin{abstract}
A case of brainstem cavernous angioma associated with hearing loss and dizziness is reported. A 25-year-old female initially complained of hearing loss in the left ear and dizziness. Six months thereafter she suddenly developed additional symptoms, and was diagnosed as having hemorrhage in the brainstem on the basis of CT scan and MRI findings. Otological examination revealed low- and high-frequency hearing loss and abnormal ABR consisting of only wave I in the left ear. Follow-up MRI showed cavernous angioma, which was surgically removed.
\end{abstract}

Key words: cavernous angioma, brainstem hemorrhage, hearing loss, neuro-otological examination

はじめに

若年者の脳幹部出血は比較的まれであり，そ の出血源としては血管奇形が多いとされている. われわれは, 難聴, めまいで発症し, 当初メ二 エール病と診断されたが, 経過観察により海綿 状血管腫が疑われ，摘出手術を行った 1 症例を 経験した. 脳幹部海綿状血管腫の手術例の報告 は少なく1) 5)，また，難聴，めまいで発症した 報告もみられていない，今回われわれは本症例 に耳科学的な面を中心に検討を加え報告する.

\section{症例}

症 例: 25歳女性

既往歴 : 特記すべきことなし
家族歴 : 伯父とその子の頸部に血管性の腫瘍 があるが詳細は不明.

現病歴：1989年 4 月初旬，なんとなくふらつ く感じがあり, 左難聴, 耳鳴に気づたた 1〜 2 日後ふらつきが強まり左に倒れそうになり, 3 日後の朝, 目を醒ますと天井が時計回りに廻 り, 嘔吐した。めまい, 難聴, 耳鳴以外の自覚 症状はなかった。某耳鼻科受診し左難聴を指摘 されメニエール病の診断で投薬をらけ, 徐々に ふらつきは消失した。そ後左難聴, 耳鳴は変 動し，8月下旬頃一時軽減したが，9月には発 症時と同程度になった。9月下旬, 感冒に罹患 し，立ちくらみ様のめまいが時々生じた．10月

1）福島県立医科大学耳鼻咽喉科学教室（主任：大谷 㦑教授）

2) 福島県立医科大学神経内科学教室（主任：山本悌司教授）

3）福島県立医科大学脳神経外科学教室（主任：児玉南海雄教授） 
1 日深夜, 突然左顔面の感覚低下，しびれが出 現し，左顔面が動かしにくい感じが生じ，体が 左によろけた。左難聴には変化がなかったが持 続していた左耳鳴がこの時消失した。また，左 口腔の温覚も消失した．四肢のしびれ，脱力， 複視，意識障害などはなかった。10月 3 日某総 合病院内科永よび耳鼻科受診。左感音難聴が認 められたが耳単純撮影, 内耳道断層撮影では異 常は指摘されなかった. 4 日当院内科受診, 神

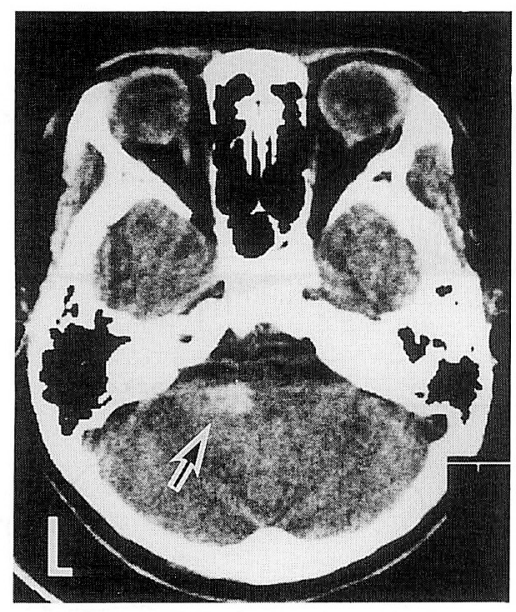

図 1 単純 CT.

左小脳脚部に高吸収域（矢印）を認める。

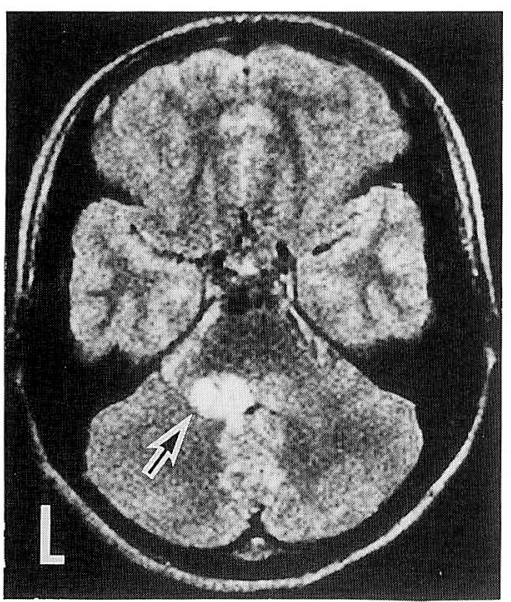

図 2 MRI. $T_{2}$ 強調画像.

小脳脚部に高信号域（矢印）を認める。
経内科紹介入院となった。この時右向きの頭位 眼振が認められ，左三叉神経領域の温痛覚の低 下, 左角膜反射の低下, 軽度の左顔面神経麻㽻 も認められた。また指鼻試験，指指試験にて左 が拙劣で，片足立ちでふらつきを認めた．入院 時の単純 $\mathrm{CT}$ にて左小脳脚部付近に高吸収域を 認め（図 1)，MRIでも同部に高信号域を認め た（図 2 ）。脳幹部出血之診断され脳動脈奇形 の疑いにて脳血管撮影を施行したが明らかな異 常所見はなかった．耳科学的検査のため13日当 科紹介となった。

初診時検查所見：鼓膜所見は正常. 純音聴力 検査で，低音部ならびに $4 \mathrm{kHz}$ 亿dip をつ高 音部の左感音難聴を認めた（図 3 ）。自記才一 ジオメトリーは Jerger $\mathbb{N}$ 型, 語音聴力検査で は語音并別能の低下がみられた。アブミ骨筋反 射は両側で陰性であった．ABR では右耳には 異常がなかったが，左耳は II波以降の消失がみ られた（図 4 ）。前庭機能検查では温度眼振検 査で左耳の反応低下を認め，注視眼振，自発眼 振, 頭位眼振に和いて右向きの眼振を認めた。 指標追跡検査，視運動性眼振検査では明らかな 異常は認められなかった（図 5 ）。

経 過：その後, 小脳症状は改善し, 聴力は

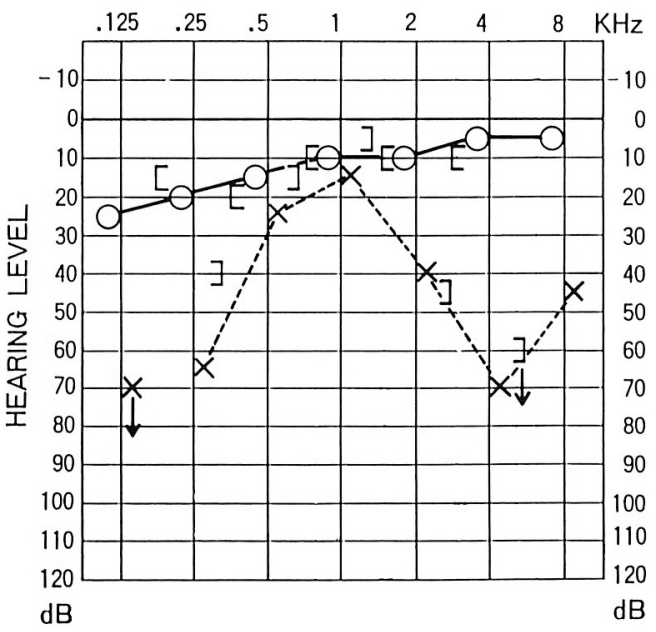

図 3 初診時オージオグラム。左耳に低音部なら びに $4 \mathrm{kHz}$ にdip をもつ感音難聴を認める 
変動したものの結局はしだいに回復した（図 6 ). 耳鳴も自覚的にも変動がみられた。顔面 のしびれが一時増悪したが，しだいにやや回復 した. 10月から数回にわたり MRI を施行した ところ，しだいに高信号域は縮小し，1990年 2 月に撮影した MRI では海綿状血管腫を疑わせ る所見を示した（図 7 ）。5 月28日摘出術目的 に脳神経外科に入院した。 6 月13日に当科で施 行した前庭機能検査では右向き頭位眼振がとき 㸱り認められるの久で, 温度眼振検査では前回 認められた左耳の反応低下は認めなかった。 6 月21日全身麻酔下に腫瘍摘出術が施行された。

手術所見：後頭下開頭により第 4 脳室底部を 露出し, striae medullares, median sulcus, facial colliculus を指標とし血管腫の位置を推 定した。第 4 脳室底を凝固焼灼して侵入し，褐 色調の被膜を有した血管腫に到達し肉眼的に全 摘出した。摘出標本の病理組織検查で海綿状血 管腫と診断された。血管腫は中小脳脚部を中心 に存在した（図 8 )。術後, 小脳症状が一過性 に出現したが新たな脳神経症状はみられなかっ た。

\section{考察}

若年者の脳幹部出血は比較的まれな疾患で， その出血源の多くは血管奇形であり, 剖検例を 含むいくつかの検討が報告されている(6) 9). 血
管奇形はしばしば亜急性ないし慢性に発症し， 動摇性で緩徐に進行したり寛解，再発すること もあり，脳幹部神経膠腫，多発性硬化症などと の鑑別が困難な症例も報告されている10) 12). 本症例はめまい, 難聴, 耳鳴で発症し, 中枢神
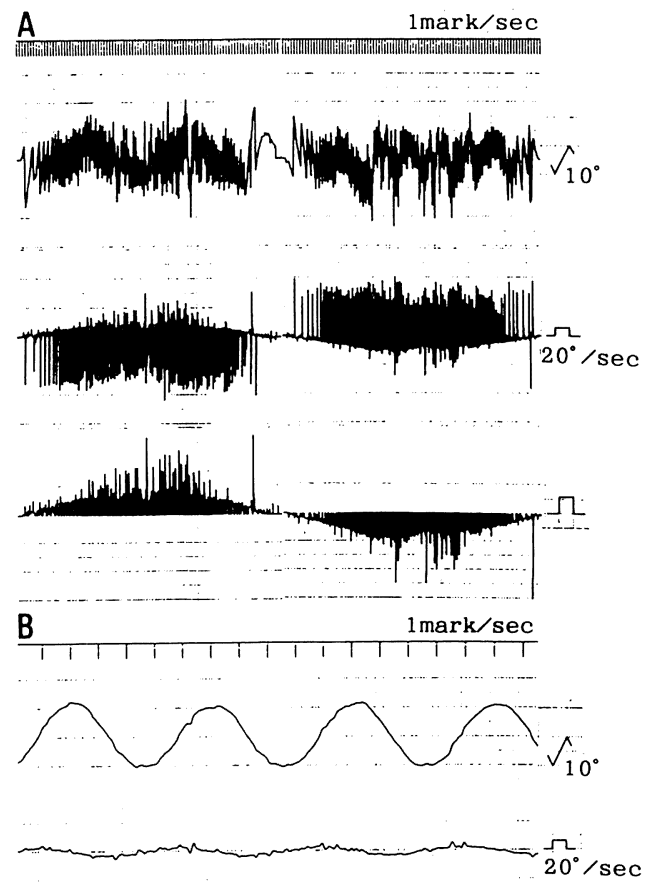

図 5 A : OKP, B : ETT

ともに明らかな異常を認めない。

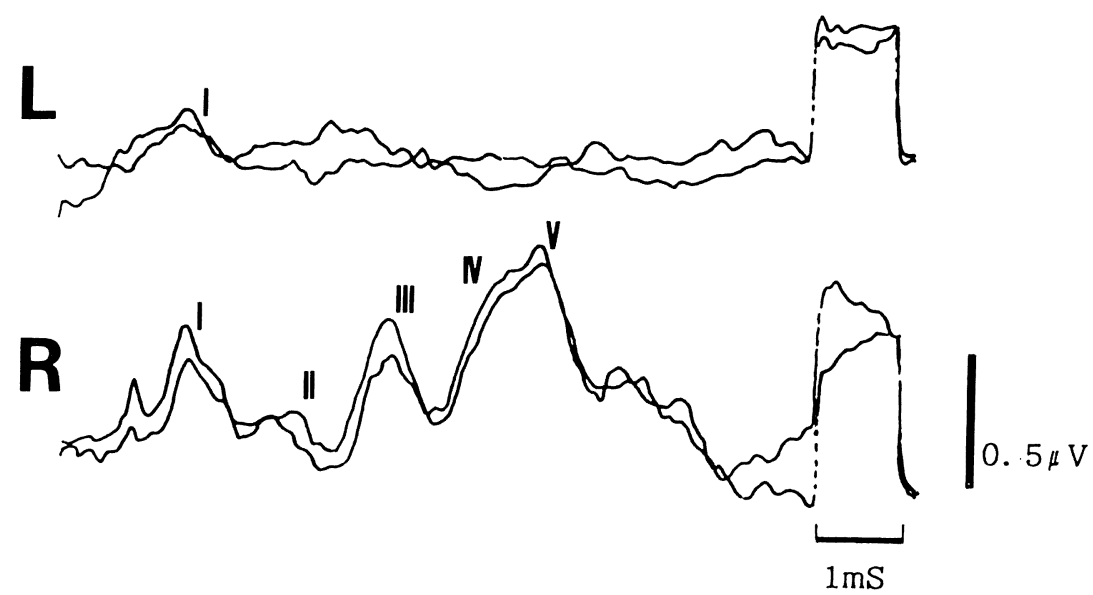

図 4 ABR. 左耳はII波以降の消失. 右耳は正常. 
経症状や他の脳神経症状がなく，第 8 脳神経症 状の寛解増悪が認められた。 このことから, 当 初は内耳病変が疑われ，メニエール病と診断さ れたが，半年後に他の脳神経症状が出現し脳幹 部病変が疑われ，CT にて脳幹部出血と診断さ れた。脳幹部の血管奇形は teleangiectasia と 海綿状血管腫の頻度が高いとされるが677)，こ れらは実際に血管撮影で存在を明らかにするこ とは困難で10)13)，画像診断上特徵的所見に乏し いとされる．本症例も血管撮影で明らかな病巣
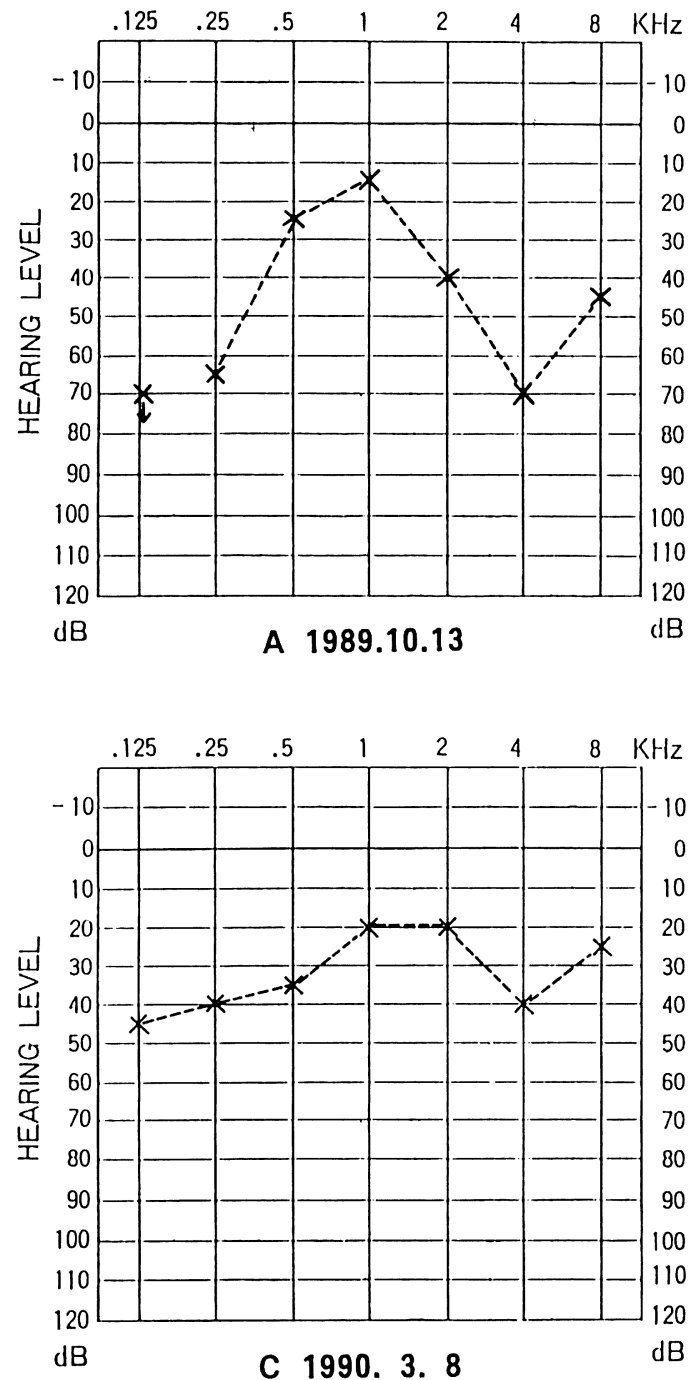

を描出することができず，MRI での経過観察 で海綿状血管腫が疑われた。このように本症例 も診断に苦慮したが，MRI の有用性3)14)を裏付 けた症例といえる。

本症例がはじめ第 8 脳神経症状のみを呈した のは蝸牛神経核, 前庭神経核あるいは第 8 脳神 経線維のみの障害があったと推測される．血管 奇形が神経症状を発現する機序としては，䯣内 への出血，血管奇形自体の増大に上る周囲への 圧迫, steal 現象による周囲組織の虚血などが
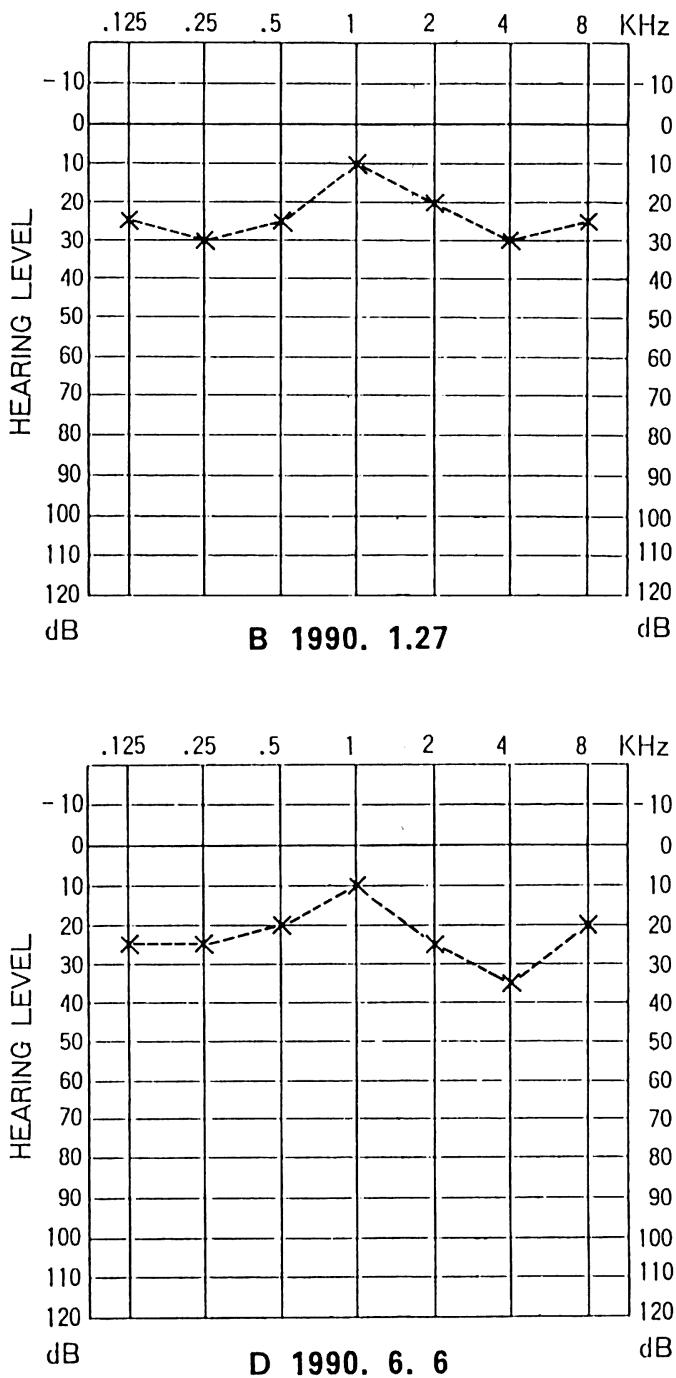

図 6 左耳聴力の変化. しだいに回復し $(\mathrm{A} \rightarrow \mathrm{B})$, やや悪化 $(\mathrm{C})$, 回復 $(\mathrm{D})$ と変化した. 
考兄られているが，本症例のように症状の寛解 増悪を繰り返す場合，血管奇形からの小出血が 原因と考えられている12). 手術所見から海綿状 血管腫は下〜中小脳脚部に認められたが，発症 時には蝸牛神経核，前庭神経核に影響を与兄る にとどまる小出血があったのではないかと推測 され，その範囲がごく限られていたため自覚的 には第 8 脳神経症状のみを呈したと考えられた。 これ対し10月の発作時はより大きい出血が起 こり, 三叉神経脊髄路核, 顔面神経線維など橋 下部から延髄上部の背外側の脳神経核, 脳神経 線維，また小脳脚を構成する神経線維に影響を 与えたと考兄られる. また，その後に顔面のし びれが増強し，聴力がやや低下したが，この時 も小さな出血があったと考光られた。

本症例の純音聴力検査で左耳は低音部ならび 高音部が障害された聴力像を呈した。また，語 音聴力低下が認められ，自記オージオメトリー では Jerger の $\mathbb{N}$ 型を示した。 後迷路難聴に拉 けるオージオグラムの型について，永瀬ら ${ }^{15)}$ は高音急墜型がほとんどみられない泳かはあら ゆるタイプが存在し，後迷路性難聴に特徴的な タイプは存在しないが，脳幹障害の約 $1 / 4$ が低 音障害型のオージオグラムを呈すると報告して いる.さらに ABR とオージオグラムの関係か
ら， I・II波のみ，あるいは I・II・II波のみ が出現する比較的下部の脳幹障害が疑われる症 例には低音障害型の難聴が多く，V波のみの変 形のような上部脳幹の障害が疑われる症例は高 音域の障害を示す例が多いとされ16)，I波のみ のものでは軽度難聴から高度難聴までさまざま の聴力を示したとの報告もある17)。また，深谷 ら18) は顔面痤攣に対する神経血管減圧手術の 際に延䯣・橋外側部に一時的乏血状態を生じた と考兄られる症例に低音障害型の感音難聴を認 め語音聴力は障害されないことを報告し，障害 部位がきわめて選択的なもので，神経核におけ る tonotopical organization ${ }^{19220)}$ とより，蝸牛神

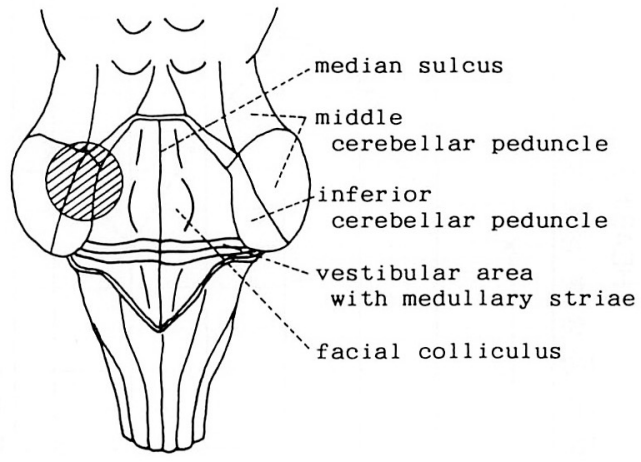

図 8 第四脸室底脳からみた海綿状血管腫（斜線 部）の位置を示すシェーマ.
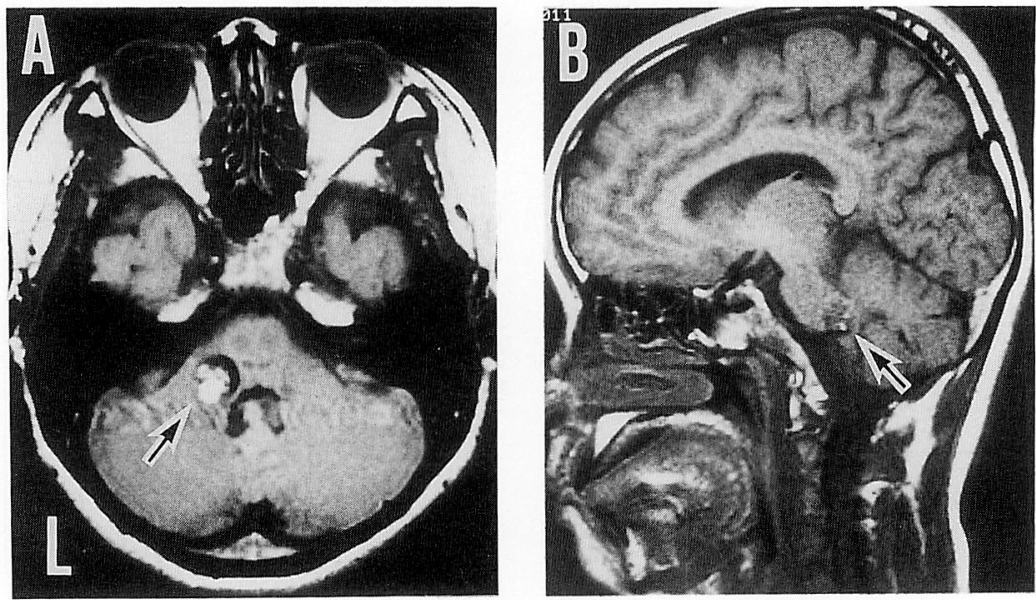

図 7 MRI. A : プロトン密度強調画像. B : $\mathrm{T}_{1}$ 強調画像. 小脳脚部汇高信号域と低信号域の混在（矢印）を認める. 
経核または上オリーブ核の外側部の障害が低音 部の障害をもたらすとしている，本症例は蝸牛 神経核の吻外側に血管腫が存在し蝸牛神経核付 近に障害を及ぼしたと考えられ，低音部の障害 は同様の機序による可能性もあると思われる.

一方, 従来, 脳幹障害の場合, 純音聴力の障害 の程度は軽度ないし正常であるとの報告が多 (15)21) 23), 一般に左右対象であるといら20). これらの場合, 両側の聴覚伝導路を含めた脳幹 の広汎な障害が推定され, 本症例のように脳幹 部でありながら一側性の難聴を示す場合や，深 谷ら ${ }^{18)}$ の症例のように低音障害型の感音難聴 を示す場合は障害部位がきわめて限局性である と思われる．また，血管腫の出血の影響の軽減 とともに純音聴力が高音域も含めて変動し回復 したことは, 蝸牛神経核とのものの圧迫または 周囲の循環障害により聴力障害が引き起こされ ていた可能性があることを裏付けるものと考え られる。

$\mathrm{ABR}$ では左耳はII波以降の消失がみられた。 血管腫の存在部位から, 解剖学的には血管腫の 影響は脳幹内の蝸牛神経核に及び，その結果 II 波以降消失したことを考えれば，II波の起源と して蝸牛神経核があげられるが，II波の起源に ついてはまだ議論の多いところであり，本症例 のみによりその起源について言及するのは困難 である。

平衡機能検査では, はじめ温度眼振検査での 左耳の反応低下と右向きの眼振が認められた. 温度眼振は半規管よりの刺激が前庭神経をとお り前庭神経核に入り脳幹を上向し眼運動系との 密接な連絡により生じるが, 本症例は血管腫が 左前庭神経核群の吻背側に存在したと考えられ, 左前庭神経核の障害が温度眼振の低下をもたら したと思われる。 また, 自発眼振, 頭位眼振も 同様の機序によるものと思われた． 6 月の平衡 機能検査でははじめ認められた左温度眼振の低 下はなく, 前庭神経核に及んだ影響が減少した ものと考えられた。また，本症例では視運動性 眼振検査, 視標追跡検査に異常を認めなかった.
視運動性眼振の発現には大脳, 中脳, 橋, 小脳 が関与しているとされ24)，また，視標追跡検査 は視運動性眼振検査とともに中枢疾患で異常を 示すことが多く, 脳幹障害では段階状, 小脳障 害では樹水状の眼球運動を呈するといわれる25). 本症例で, これらの検査時には, 病変が脳幹部 の比較的狭い範囲に限局していたため異常を示 さなかったと考えられた。

本症例のように, めまい, 難聴などの症状を 訴えた際, 当初内耳性の疾患が疑われるもので も, 脳幹部などに中枢性の病変が存在している こともあり，十分な検索と経過観察が必要であ ると思われた。

\section{まとめ}

難聴, めまいで発症した脳幹部海綿状血管腫 の 1 症例について耳科学的な面を中心に検討を 加え報告した，症例は難聴，めまいで発症した ため, 当初内耳性の疾患が疑われたが, 後に種 々の脳神経症状が出現し脳幹部海綿状血管腫と 診断された。このように難聴, めまいなどの症 状から内耳性の疾患が疑われるものでも, 脳幹 部などに中枢性の病変が存在していることもあ り，十分な検索が必要であると思われた。

本論文の要旨は第91回日本耳鼻咽喉科学会総会に おいて発表した.

\section{参考文献}

1）横山正人, 喜多村健, 菅澤 正, 他: 術中モ二 タ-Auditory Brainstem Response (ABR) で興 味深い所見が得られた脳幹血管腫の 1 症例.耳 喉頭頸 $62: 51 \sim 55,1990$.

2) 黒岩俊彦, 藤本 司, 青柳昌樹, 他 : 第 4 脳室 底部海綿状血管腫の剝出例. Neural Med Chir (Tokyo) $23: 305 \sim 310,1983$.

3）奥 達也, 米満 勤, 藤原 悟, 他: 橋背部海 綿状血管腫の 1 手術治験例一診断上 MRI の有 用性. 脳外 $15: 159 \sim 164.1987$.

4）隈部俊宏, 鈴木倫保, 吉本高志, 他 : Subtemporal \& Trans-Temporial Approach により摘 出した脳幹部海綿状血管腫の 1 例. 脳外 16 : 1193 1197, 1988. 
5) Terao H, Hori $T$, Matsutani M, et al : Detection of cryptic vascular malformations by computerized tomography. Report of two cases. J Neurosurg 51 : 546 551, 1979.

6) Teilmann $K:$ Hemangiomas of the pons. Arch Neurol Psychiat 69 : 208 223, 1953.

7) McCormick WF, Hardman JM and Boulter TR : Vascular malformation ("angiomas") of the brain, with special references to those occurring in the posterior fossa. J Neurosurg 28 : $241 \sim 251,1968$.

8) Stahl SM, Johnson KP and Malamud N : The clinical and pathological spectrum of brainstem vascular malformations. Long-term course simulates multiple sclerosis. Arch Neurol 37 : 25 29, 1980.

9）高橋立夫, 中村鋼二, 安藤和彦: 若年性特発性 脳幹出血の 4 例. CT 研究 $7: 533 \sim 542,1985$.

10) Abrom IF, Yessayam L, Shillito J, et al : Spontaneous intracerebral hemorrhage in patients suspected of multiple sclerosis. J Neurol Neurosurg Psychiatry $34: 157 \sim 162,1971$.

11）外山孚, 本多拓, 植木幸明: 脳橋膠腫, 多 発性硬化症を疑わせた特発性脳橋血腫の 1 例. 脳外 $6: 1109 \sim 1112,1978$.

12）丸尾泰則, 田代邦男, 福嶋隆三, 他 : 脳幹部血 管奇形の臨床症候について. 脳卒中 $9: 218 \sim$ 225, 1987.

13）小林啓志, 外山 孚, 栗田 勇, 他 : 若年者の 原発性橋出血. 脳神経 $30: 749 \sim 756,1978$.

14）都筑信介, 印東利勝, 高橋 昭: 脳幹海綿状血 管腫の MRI. 神経内科 $27: 125 \sim 126,1987$.

15）永瀬茂代, 伊藤真郎, 木村 仁, 他 : 低音障害 型感音難聴を示した脳幹腫瘍例.耳鼻臨床 83 ：
1337 1342, 1990.

16）飯塚尚久, 伊藤真郎, 高瀬二郎, 他 : 後迷路障 害例に拈ける ABR と聴力の関係について（第 一報). Audiorogy Jpn 32 : 178 179, 1989.

17）細谷 睦, 伊藤真郎, 石井恵理, 他: ABR の 異常波形と純音・語音聴力. Audiorogy Jpn $28: 90 \sim 91,1985$.

18）深谷 卓，福島孝徳，野村恭也：延髄外側部の 障害による聴力障害. 神経内科 $28: 491 \sim 496$, 1988.

19) Rose J, Galambos $R$ and Hughes JR : Microelectrode studies of the cochlea. Hosp Bull 104 : 211 251, 1959.

20) Tsuchitani C and Boudreau JC : Single unit analysis of cat superior olive segment with tonal stimuli. J Neurophysiol $29: 684 \sim 697$, 1966.

21）佐藤恒正, 伊藤真郎, 野呂久公 : 頭蓋内疾患と 語音聴力. Audiorogy Jpn $20: 334 \sim 347,1977$.

22）細川 智, 相馬博志, 北條和博, 他 : 脳幹性難 聴の診断について.耳鼻臨床 $76: 1873 \sim 1880$, 1983.

23) Jerger $\mathrm{J}$ and Jerger $\mathrm{S}:$ Auditory findings in brain stem disorders. Arch Otolaryng $99: 342$ $\sim 350,1974$.

24）時田 喬：視運動性眼振検査. 神経耳科学 II (時 田 喬, 他編). 166 187頁, 金原出版, 東京, 1985.

25）上田良穂, 鈴木淳一, 切替一郎：視標追跡検査. 耳鼻臨床60：918～920, 1967.

$\left(\begin{array}{l}\text { 別刷請求先: 佐久間仁 } \\ \overline{\mathbf{T}} 960-12 \text { 福島市光が丘 } 1 \\ \text { 福島県立医科大学耳鼻咽喉科学教室 }\end{array}\right)$ 